\title{
The preregistration houseman in general practice
}

\author{
G K FREEMAN, C R COLES
}

\begin{abstract}
During 1979-80 an experimental preregistration house physician post in general practice was conducted at Aldermoor Health Centre in Southampton in rotation with medical posts at Southampton General Hospital. Ten house physicians took part in the experiment that lasted for 19 months and each doctor spent two months in general practice. The house physicians settled quickly into general practice and found the experience both enjoyable and worth while. The hospital consultants, general practitioners, and the house physicians themselves thought that this was a valuable extension to preregistration education. The experiment raised several questions, some of which were specific to the type of rotation organised and others that were more fundamental to the whole concept of the preregistration house physician in general practice. If the experiment is to be repeated a longer period in general practice is strongly recommended. A full year rotation is suggested with four months each of surgery, medicine, and general practice.
\end{abstract}

\section{Introduction}

The preregistration year has been a legal requirement since the Medical Act of 1950. Although experience in general practice, specifically in a health centre, was envisaged by the Goodenough Committee in $1944^{1}$ this has not previously been attempted.

\footnotetext{
Faculty of Medicine, University of Southampton, Southampton, Hants

G K FREEMAN, MRCP, MRCGP, senior lecturer (Primary Medical Care Group, Aldermoor Health Centre)

C R COLES, BSC, MA, lecturer (Medical Education Group, Southampton General Hospital)
}

The new medical school at Southampton was only the second to come into existence in the United Kingdom since 1893. The first students qualified in 1976, and there are now nearly 120 graduates each year. Although Wessex now imports fewer housemen from other medical schools, it has been necessary to expand the number of local posts. The background of a long tradition of postgraduate education in general practice in Wessex and an undergraduate department of primary medical care enabled the postgraduate dean to consider the introduction of an experimental preregistration post in general practice.

We report our experience with 10 house physicians undertaking two-month full-time attachments from February 1979 to August 1980.

\section{Aims}

Once a two-month attachment in general practice was agreed (see method) it became clear that the house physicians would have to concentrate on acute and short-term medical conditions at the expense of long-term management and continuity of care.

The educational aims for the preregistration attachment were to:

(1) Appreciate the wide range of illness in the continuity;

(2) Become aware of the various ways symptoms presented;

(3) Recognise the relationship between physical, psychological, and social factors in diagnosis and management;

(4) Learn to communicate with colleagues both in general practice and in hospital; and

(5) Develop clinical skills in the general practice setting and learn of the facilities available to the general practitioner.

\section{Method}

\section{ROTATION}

A rotation was arranged between two medical firms at the teaching hospital and the group practice at Aldermoor Health Centre half a mile away $(0.8 \mathrm{~km})$. Three house physicians were appointed every six months to the rotation, each of them doing two months general practice in turn (figure). As the rotation could be either a first or a second 
preregistration post, the general practice component could happen at any time during the preregistration year. The house physicians were able to live in at the hospital. All those appointed owned cars, and a milage allowance was paid by the district health authority. The oncall commitment attracting extra-duty payments was adjusted to the equivalent payment for the hospital component posts.

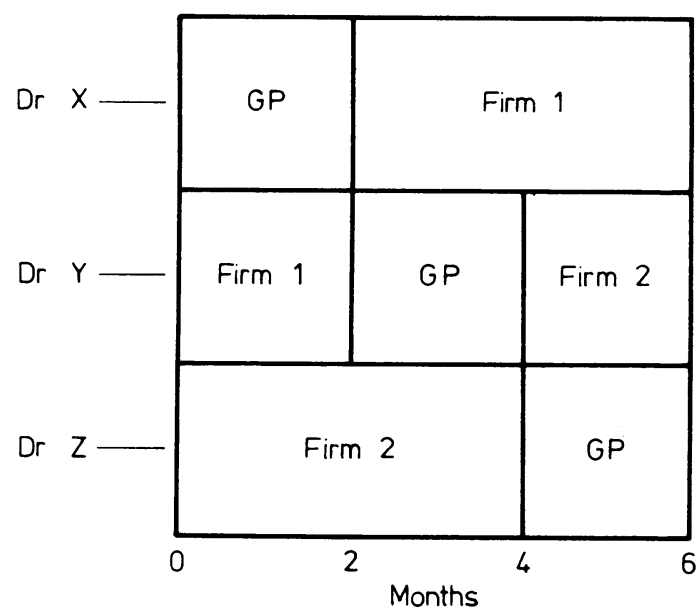

Rotation of three house physicians through general practice and the two hospital medical firms.

\section{THE PRACTICE}

Aldermoor Health Centre houses a single general practice of 8200 patients. During 1979-80 there were five principals, one assistant, and one trainee. All principals have full-time academic appointments with Southampton University and are expected to devote at least half their time to teaching and research. There is a full complement of attached community nurses, health visitors, and a midwife. No social worker is attached, but a clinical psychologist had at least one session weekly during the experiment.

\section{EVALUATION}

The house physicians kept medical records on the computerised system CLINICS used at Aldermoor Health Centre. ${ }^{2}$ This enabled us to analyse the type of illness seen, drug treatment, and investigations ordered. Four house physicians were interviewed in depth by one of us (CRC) about their experience in general practice. As a result of these interviews six issues were defined as likely to influence the success of the post: (a) quality of supervision, $(b)$ time allowed with each patient (was it too much?), (c) ability to focus on problems from the patient's point of view, $(d)$ not being allowed to prescribe, $(e)$ timing of the general practice rotation within the preregistration year, and $(f)$ effect on career prospects.

A questionnaire inviting comment about each of the six issues was sent to all 10 house physicians. They were given ample space to respond in their own words. Because numbers were small it was possible to group similar answers together. These are presented below in the form of representative quotations that reflect common viewpoints.

\section{Results}

This experimental rotation began in February 1979 and was planned to run for two years. The experiment was discontinued in August 1980 when one of the participating house physicians had to withdraw because of ill health. No locums were employed during holidays so the 10 house physicians completed 16 months' clinical work.

\section{PARTICIPATING HOUSE PHYSICIANS}

Some characteristics of the 10 house physicians are summarised in table I. Four were women, two were married, two had been "mature" students, and nine were Southampton graduates. Six of the 10 wer doing their first preregistration job, and three had had no hospital experience at all since qualification. Four expressed a strong interest in general practice as a future career and one of these, $\mathrm{Dr} \mathrm{B}$, made this decision during the rotation. These features suggest that our 10 doctors were a representative sample of recent medical graduates in Southampton.

TABLE I-Characteristics of the 10 house physicians

\begin{tabular}{|c|c|c|c|c|c|c|c|}
\hline $\begin{array}{l}\text { House } \\
\text { physician }\end{array}$ & Sex & $\begin{array}{c}\text { Marital } \\
\text { status }\end{array}$ & $\begin{array}{l}\text { "Mature student" } \\
\text { on entry to } \\
\text { medical school }\end{array}$ & $\begin{array}{c}\text { Declared } \\
\text { career intention } \\
\text { in general practice }\end{array}$ & $\begin{array}{l}\text { Position in } \\
\text { preregistration year } \\
\text { (I-VI two-month periods) }\end{array}$ & $\begin{array}{c}\text { Southampton } \\
\text { graduate }\end{array}$ & $\begin{array}{l}\text { Questionnaire } \\
\text { answered }\end{array}$ \\
\hline $\begin{array}{l}\text { A } \\
\text { B } \\
\text { C } \\
\text { D } \\
\text { E } \\
\text { F } \\
\text { G } \\
\text { H } \\
\text { J } \\
\text { K }\end{array}$ & $\begin{array}{l}F \\
M \\
M \\
F \\
M \\
M \\
F \\
M \\
M \\
M \\
F\end{array}$ & $\begin{array}{l}\mathbf{S} \\
\mathbf{S} \\
\mathbf{S} \\
\mathbf{S} \\
\mathbf{S} \\
\mathbf{S} \\
\mathbf{M} \\
\mathbf{S} \\
\mathbf{S} \\
\mathbf{M}\end{array}$ & $\begin{array}{l}\text { No } \\
\text { Yes } \\
\text { No } \\
\text { No } \\
\text { No } \\
\text { No } \\
\text { Yes } \\
\text { No } \\
\text { No }\end{array}$ & $\begin{array}{l}\text { No } \\
\text { Yes } \\
\text { No } \\
\text { Yes } \\
\text { No } \\
\text { No } \\
\text { Yes } \\
\text { No } \\
\text { Yo } \\
\text { Yes }\end{array}$ & $\begin{array}{c}\text { IV } \\
\text { II } \\
\text { VI } \\
\text { I } \\
\text { II } \\
\text { III } \\
\text { I } \\
\text { VI } \\
I^{*}\end{array}$ & $\begin{array}{l}\text { Yes } \\
\text { Yes } \\
\text { Yes } \\
\text { Yes } \\
\text { Yes } \\
\text { Yes } \\
\text { Yes } \\
\text { Yes } \\
\text { Yes } \\
\text { No }\end{array}$ & $\begin{array}{l}\text { Yes } \\
\text { No } \\
\text { Yes } \\
\text { Yes } \\
\text { Yes } \\
\text { Yes } \\
\text { Yes } \\
\text { Yes } \\
\text { Yes } \\
\text { Yes }\end{array}$ \\
\hline
\end{tabular}

${ }^{*} \mathrm{Dr} \mathrm{K}$ completed only one month in general practice.

\section{HOUSE PHYSICIANS' CLINICAL ROUTINE}

Each consulting session at the health centre was run in association with a general practitioner with the opportunity for active clinical supervision of each patient rather than a review at the end of the session. Similarly with home visiting, the house physician made an initial assessment and reported back either in person or by telephone before completing the consultation either alone or with his supervisor. Follow-up visits might be performed by the house physician alone especially towards the end of the two months. The house physicians were not allowed to sign prescriptions, although they were expected to prepare them for signature by a fully registered colleague. In addition to scheduled clinical work each house physician was allocated one or two sessions a week for personal study (including follow-up of interesting patients at home).

\section{CLINICAL EXPERIENCE}

The 10 house physicians were directly responsible for 3868 consultations in 16 months (excluding holidays), an average of 55 a week. They normally took seven "surgeries" a week with five patients in each and would visit 10-12 patients a week on midday visiting rounds. The remaining patients were seen at nights and weekends. The house physicians saw $18.4 \%$ of their patients at home compared with a rate of $11.3 \%$ for the practice as a whole. Compared with the health centre doctors, the house physicians saw fewer elderly patients and more older children and young adults (table II). Our vocational trainees' consultations showed a similar age distribution except that they included a small excess of younger children aged 0-4 years. Both housemen and trainees saw slightly fewer female patients than the general practitioners. 
The housemen's clinical work suggested that a substantial proportion of their experience was with acute self-limiting conditions and symptomatic presentations (table III). Depression, anxiety, and other psychological problems were less often recorded by the housemen.

TABLE II-House physician-patient encounters classified by age and sex compared with trainees and with all health centre doctors

\begin{tabular}{|c|c|c|c|}
\hline & $\begin{array}{c}\text { House physicians } \\
(\mathrm{n}=3868) \\
\left({ }^{\circ}(\mathrm{)})\right.\end{array}$ & $\begin{array}{c}\text { Trainces } \\
(\mathrm{n}=4785) \\
\left({ }_{0}\right)\end{array}$ & $\begin{array}{c}\text { All doctors } \\
(\mathrm{n}=56545) \\
(\%)\end{array}$ \\
\hline $\begin{array}{l}\text { Patient age group: } \\
0-4 \\
5-14 \\
15-44 \\
45-64 \\
\geqslant 65\end{array}$ & $\begin{array}{l}12 \cdot 2 \\
16 \cdot 5 \\
46 \cdot 3 \\
13 \cdot 0 \\
12 \cdot 1\end{array}$ & $\begin{array}{l}14 \cdot 8 \\
16 \cdot 3 \\
44 \cdot 6 \\
12 \cdot 7 \\
11 \cdot 6\end{array}$ & $\begin{array}{l}12 \cdot 8 \\
11 \cdot 9 \\
42 \cdot 9 \\
17 \cdot 3 \\
16 \cdot 0\end{array}$ \\
\hline $\begin{array}{l}\text { Sex: } \\
\quad \text { Male } \\
\text { Female }\end{array}$ & $\begin{array}{l}44 \cdot 2 \\
55 \cdot 8\end{array}$ & $\begin{array}{l}43 \cdot 4 \\
56.6\end{array}$ & $\begin{array}{l}41 \cdot 7 \\
58 \cdot 3\end{array}$ \\
\hline
\end{tabular}

TABLE III-Morbidity classifications of patients seen by house physicians

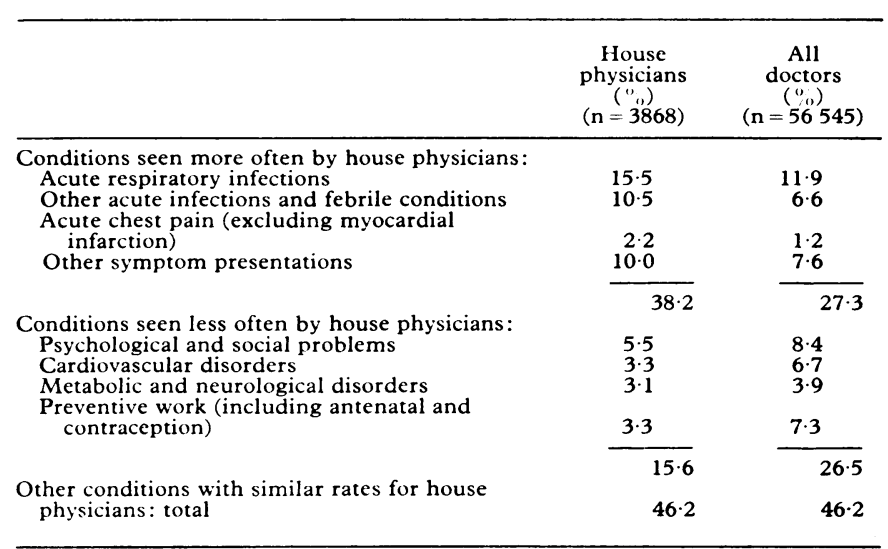

TABLE IV-Tests and $x$-ray examinations. (Rates for house physician requests compared with rates for all doctors per 100 consultations)

\begin{tabular}{lcc}
\hline & $\begin{array}{c}\text { House physicians } \\
(\%)\end{array}$ & $\begin{array}{c}\text { All doctors } \\
(\%)\end{array}$ \\
\hline Microbiology & $6 \cdot 2$ & $3 \cdot 7$ \\
Clinical chemistry & $4 \cdot 9$ & $3 \cdot 2$ \\
Haematology & $4 \cdot 5$ & $3 \cdot 7$ \\
Pregnancy tests & $0 \cdot 9$ & $0 \cdot 8$ \\
Other tests & $1 \cdot 0$ & $1 \cdot 2$ \\
$X$-ray examinations & $2 \cdot 3$ & $1 \cdot 4$ \\
\hline Total & $19 \cdot 7$ & $14 \cdot 0$ \\
\hline
\end{tabular}

\section{PRESCRIBING}

The house physicians prescribed at a low overall rate; for every 100 encounters 59 drugs were recorded compared with a practice average of 75 at face-to-face consultations. The reduction was most pronounced with cardiovascular drugs and diuretics, where the house physicians recorded fewer than half the practice average. Other drug classes, including cough mixtures and tranquillisers, were all prescribed less often by the house physicians; the one exception was antibiotics, which comprised $30 \%$ of all their prescribing compared with a practice proportion of $20 \%$. Twenty preparations accounted for over half the drugs prescribed by house physicians ( $52 \%)$; the top six were penicillin $\mathrm{V}$, amoxycillin/ampicillin, brompheniramine maleate (Dimotapp) preparations (adrenergic/antihistamine), diazepam, aspirin, and salbutamol.

\section{TESTS AND X-RAY EXAMINATIONS}

The house physicians could order tests and investigations without counter-signatures by their supervisors. They ordered more investigations than the general practitioners, especially in microbiology and radiology (table IV).

\section{RESULTS OF QUESTIONNAIRE}

Nine replies were received, one doctor being abroad at the time.

\section{Supervision}

Nearly all comment on supervision was highly favourable. (Dr E: "Very reassuring and not obtrusive.") Less favourable remarks included: Dr J: "Some supervisors were more prepared to allow independent decisions . . . occasionally one felt one was obliged to follow the supervisors' policies for no particular reason. The fact that the supervisor was often busy was a nuisance."

\section{Time allowed with each patient-was it too much?}

Time allowed for each consultation was normally 15 minutes, nearly double the practice average. No one thought this too little and four said it was indeed too much. Dr E, however, remarked that perhaps general practitioners should have more time and Dr G found this a strange question, "suspecting that anyone having too much time was finding it difficult to talk to patients in general terms outside the immediate medical problem."

\section{Ability to "focus" on patients' problems}

This feature of general practice attracted favourable comment together with a desire to apply the lessons learnt to hospital practicefor instance, Dr G: "It made one more tolerant of certain patients when admitted to hospital" and $\mathrm{Dr} \mathrm{H}$ : "This can hopefully be extrapolated to the hospital situation." Nevertheless, this did not always make things easy as Dr C remarked: "Many patients had problems which were very difficult to assess."

\section{Not being allowed to prescribe alone}

Three doctors found not being allowed to prescribe alone timeconsuming or frustrating while two found it "no problem." The remaining four doctors found only occasional frustrations. Dr A pointed out, "it made writing a prescription about the most difficult way to end a consultation rather than the easiest." Drs G and J suggested that house physicians in general practice be allowed to prescribe independently from a limited list of drugs.

\section{Timing of the general practice post during the preregistration year} (see table I)

None of the doctors felt handicapped by their own sequence of posts but Drs $\mathrm{D}$ and $\mathrm{K}$, two of the three house physicians who started the year in general practice, thought that they would have benefited from hospital experience first; on the other hand, the third, Dr G, preferred starting in general practice to being "thrown in the deep end in hospital." Most of those who had done their general practice towards the end of their year had doubts about an earlier attachment, while Dr C thought that it was "not a good idea at all" to start the year in general practice.

\section{Effect on career prospects}

Most made thoughtful and appreciative comments about the widening of their experience, although Dr E remarked that at subsequent interviews for hospital posts, "it has been a constant topic of conversation, there is a slight majority who thought that it was a bad idea." 
Dr K said, "I was confirmed in my feelings that I should like to do general practice" and Dr G agreed. Dr F, who had been finding her hospital experience very hard, said, "it made medicine enjoyable for me again."

\section{GENERAL COMMENTS}

All thought that the experience had been well worth while: "I definitely think that this post should go on" (Dr C) and "I think the rotation was definitely of benefit and ought to be continued" (Dr J). Dr A remarked, "some people felt that we missed out on hospital medicine with only four months as a hospital house physician, I certainly did not feel that to be the case." Dr E said: "Two months was too short" but added "I would have reservations if the general practitioner part was not in a teaching practice." Finally, several doctors noted that the general practitioner rotation was "geared to the houseman's ability to cope" in a way that is difficult to arrange in hospital.

\section{Discussion}

The General Medical Council's "code of good practice" in relation to the preregistration year ${ }^{3}$ suggests that there should be an emphasis on acute clinical work and that the "teaching by in-service clinical training should be the primary objective." The code also suggests that there should be "adequate time for his further education and sufficient free time." Our experience suggests that these criteria could well be met in general practice.

The house physicians saw a wide variety of patients in terms of age, sex, and morbidity. Compared with the practice average, they saw more older children and young adults and fewer middleaged and elderly adults. This is similar to the experience of other new entrants to practices, such as our own vocational trainees, except that the trainees saw more rather than fewer young children. Many of our house physicians commented on their lack of experience and confidence in paediatrics, and this may have led them to avoid very young patients. The house physicians' smaller recording of psychological and social disorders may suggest inability or reluctance to recognise these conditions in an area that is noted for observer variation. ${ }^{4}$ Nevertheless, this is consistent with Carney's finding that trainees see acute respiratory conditions rather than chronic illness or mental conditions. ${ }^{5}$

The prescribing pattern of the house physician reflects the morbidity of the patients they saw with an emphasis on drugs for acute respiratory conditions. Similarly, the house physician's lower prescribing rate overall may partly be due to their smaller involvement with chronically ill patients, but their own comments indicate that the need to get a counter-signature from their supervisor was felt to be a deterrent to prescribing. The fact that 20 preparations accounted for over half their prescribing supports the idea that house physicians in general practice should be allowed to prescribe independently from a limited list of drugs. The relatively high rate of use of antibiotics, however, suggests the possibility that, faced with the actual management of many patients with minor respiratory illness, the house physicians felt pressure to prescribe active drugs without firm clinical indications. On balance we consider that the supervision of the prescription is an important educational tool at this stage and should not be abandoned. The higher rate of investigation may be a combination of the uncertainty of the house physicians, their recent contact with hospital practice, and a willingness to use their new-found status as "doctor." A case can be made for investigations to be the subject of scrutiny in any future programme.

The remainder of our evaluation concentrated on the views of the house physicians themselves. Recent educational research has given more attention to subjective data ${ }^{6}$ This renewed interest is summed up thus: "If educational research is to be useful, possible implications for action must be pointed out by those closest to the data, even though their value judgments may intrude." We were studying a small number of subjects who did not form a homogenous group, where both supervisors and housemen were learning as they went along. It was not possible to control for crucial variables such as novelty and enthusiasm. Therefore we began with four informal interviews to identify important issues from the point of view of the house physicians on which the questionnaire was then based.

The small numbers made it easy to identify common responses, which have already been quoted. In particular the answers to question three (the ability to focus on problems from the patient's point of view) indicated an awareness of psychological and social factors and an appreciation of the difficulties sometimes encountered by general practitioners when arranging hospital admissions.

Both formal and informal responses from the house physicians themselves have shown strong support for the concept of preregistration work in general practice. Perhaps this was summed up by $\mathrm{Dr} \mathrm{A}$ who remarked, nearly 18 months after doing the job, "I'm very glad I did the job ... if I continue in hospital medicine it will have given me a view of general practice which few hospital doctors get."

Several problems need to be overcome before such posts could be widely introduced. On the hospital side one of the consultants concerned has said, "my main qualm about the job is that the two months in general practice may not be seen by some of our students to be in their interests (wrongly in my view). As a result it may be that we will discourage some of our more outstanding students from applying for a house post in the professorial medical unit." But the main problems lie in general practice itself. General practice is centred on the one-to-one consultation of patient with doctor whereas the houseman working in hospital will have his work checked by one or more senior doctors. Moving the houseman to general practice thus implies either that patients should be seen a second time, resulting in more patientdoctor contacts or that reliance is placed on an inexperienced doctor for a single face-to-face contact. At Aldermoor Health Centre the general practitioners found the presence of a houseman increased their workload because of the consultation time taken up by supervision, whereas in hospital the houseman is a recognised member of the medical team. This state of affairs was highlighted when a hospital house physician fell ill; the general practice house physician was transferred to take his place, thus terminating the experiment early. This was to the satisfaction of all but the house physician who had to move! Another problem was that the brevity of the attachment meant a rapid turnover of new faces in the practice. There were occasions when this put strain on doctors, staff, and patients. This problem was exacerbated by the fact that the practice was already taking part in both undergraduate and postgraduate teaching.

Some of these problems would be eased by a longer attachment in general practice. Initial close supervision could then be relaxed when the house physicians' abilities were known. There would be fewer newcomers in the practice, and most house physicians would be able to make a small but worth-while service contribution towards the end of their stay. Six months would be ideal but four months could be a workable compromise without detracting too much from hospital medicine and surgery.

\section{Conclusions and recommendations}

We would emphasise that in our opinion this experimental general practice preregistration post was sufficiently successful in educational terms to be repeated on a wider scale in normal NHS general practice. Such practices should have the following characteristics:

(1) Some teaching experience but without a busy concurrent teaching programme at undergraduate and trainee level.

(2) Willingness to devote substantial time to teaching, almost certainly more than that required for a trainee. This might require appropriate payment. 
(3) Available space for the houseman to consult alone.

(4) Living accommodation available on the premises or sufficiently close to hospital accommodation.

A longer attachment is probably essential, and we suggest at least four months. This would also make it feasible to direct some older and more chronically ill patients to the house physician. Such a four-month post would be part of a one-year rotation together with four months each of hospital medicine and surgery. We suggest that the educational aims should be extended to include the hospital medical and surgical parts of the preregistration year and that achievement of these aims should be monitored.

We are very grateful to the house physicians who gave much time in considering our persistent inquiries, to Professor John Bain for his helpful criticism, and to Mrs Jean Gibson for typing the manuscript.

\section{References}

${ }^{1}$ Ministry of Health, Department of Health for Scotland. Report of the Inter-departmental Committee on medical schools. London: HMSO, 1944: 200. (Goodenough Report.)

${ }^{2}$ Basden A, Clark EM. CLINICS : clinical information and inquiry computer system. In: Clark EM, Forbes JA, eds. Evaluating primary care. London: Croom-Helm, 1979.

${ }^{3}$ General Medical Council. Code of good practice for universities and medical schools in relation to the pre-registration year. London: GMC, 1973.

4 Thomas KB. Temporarily dependent patient in general practice. Br Med $\mathcal{F}$ $1974 ; \mathrm{i}: 625-6$.

${ }^{5}$ Carney, TA. Clinical experience of trainees in general practice. $\mathcal{f} R \mathrm{Coll}$ Gen Pract $1979 ; 29: 40-4$.

${ }^{6}$ Hamilton D, Jenkins D, King C, MacDonald B, Parlett M. Beyond the numbers game: a reader in educational evaluation. London: Macmillan, 1977.

${ }^{7}$ Entwistle N, Wilson J. Degrees of excellence: the academic achievement game. London: Hodder and Stoughton, 1977.

(Accepted 15 April 1982)

\title{
Ethics of a predictive test for Huntington's chorea
}

\author{
S THOMAS
}

\begin{abstract}
"Index Medicus" and 18 other publications have been consulted in an attempt to provide an easily assimilated selection of the recently published and widely dispersed material relevant to the ethical debate the editors of the "BMJ" called for on 4 March 1978.' The medical profession is shown to be deeply divided on the ethics of a predictive test for Huntington's chorea. Some members are already using the prospect of a reliable test as an inducement to potential transmitters of this incurable hereditary disease to postpone procreation. Other members would prefer to see any future test withheld from every applicant until such time as radically improved means of treatment or a cure is discovered. The evolution of generally acceptable professional guidelines requires further informed debate.
\end{abstract}

\section{Introduction}

Huntington's chorea is a progressive and incurable disease of the central nervous system transmitted through an autosomal gene with complete penetrance. ${ }^{2}$ Each child of an affected person has a $50 \%$ chance of inheriting the responsible gene, ${ }^{3}$ but carriers cannot be identified until there are clinical signs of the disease itself. By the time these appear, a carrier may well have procreated: roughly two-thirds develop symptoms after the age of 29 years. ${ }^{4} \mathrm{~A}$ predictive test would break new ground by making it possible to identify carriers before they developed the disease. Non-carriers, who now have to wait until late middle or old age before they can be certain that they have not inherited the gene, could learn of their freedom much earlier.

Almost all of the published attempts ${ }^{5}$ to develop a definitive test have proceeded on the assumption that the Huntington's chorea gene generates measurable defects long before the clinical features become evident. ${ }^{6}$ If this hypothesis is true and the gene

London NW1

$S$ THOMAS does prove to be "switched on" in utero or at any rate early rather than late in the presymptomatic period of a carrier's life, the deliberations of those professional and lay contributors to the ethical debate who are already taking the eventual development of a test for granted will, in retrospect at least, seem timely. Nor could we regard them as entirely wasted if relevant investigations with a different rationale-analysis of the gene's genetic linkage relations, ${ }^{5}$ for example-yield all the information that is theoretically obtainable.

At least four features of an ideal test in vivo have been specified in professional publications. Such a test would entail little or no risk to the subject ${ }^{7}$; it would discriminate between carriers and non-carriers with no false positives or false negatives ${ }^{1}$; it would produce no ambiguous results ${ }^{1}$; and its results would be inscrutable to subjects. ${ }^{1}$ Although additional features come readily to the minds of individuals at risk, most fantasised additions (prior indication of a given carrier's age at onset, the subsequent survival period, and the nature and severity of symptoms, for example) appear to be contingent on truly prodiguous advances in our understanding of the disease's aetiology. For this reason the mainstream of the ethical controversy has been concerned with the impact on the status quo of a definitive but relatively straightforward test.

\section{The status quo}

EXTENT OF GENETIC COUNSELLING

At present, only some of the individuals known to be at $50 \%$ risk of developing Huntington's chorea are made aware of the medical and genetic implications without delay. A poll ${ }^{4}$ in the United Kingdom of choreic families belonging to the Association to Combat Huntington's Chorea, a voluntary lay organisation, showed that whereas couples are quite likely to be cautioned about the dominant inheritance pattern if they have not started a family when the relevant diagnosis is made, couples who already have a young family at the time of diagnosis may not be fully informed until their offspring are old enough to be told. Some family doctors who have seen a generation or more with Huntington's chorea in a given family apparently choose not to tell young women until after they have married and had about two children. Respondents who had produced children in ignorance of the genetic consequences bitterly resented not being informed at the time and usually regretted having children once they had learnt the 